\title{
PASAL 66 AYAT (1) UNDANG-UNDANG JABATAN NOTARIS DAN TINDAK PIDANA KORUPSI
}

\author{
Hendry Julian Noor \\ Fakultas Hukum Universitas Gadjah Mada Yogyakarta \\ Email : hendryjuliannoor@yahoo.co.id
}

\begin{abstract}
ABSTRAK
Penerapan Pasal 66 Ayat (1) hanyalah dilakukan pada ranah pidana, bukan perdata. Jika terkait dengan tindak pidana umum, maka izin dari MPD (kini Majelis Kehormatan Notaris) itu bersifat wajib atau imperatif, jika tidak, maka proses perkara itu seharusnya dapat ditangguhkan dulu sampai ada izin dari MPD, sebagai bentuk perlindungan Jabatan Notaris, terkecuali jika Notaris itu akan diperiksa dalam perkara pidana yang tidak ada hubungannya dengan pembuatan akat Notaris tersebut.

Apabila berhadapan dengan tindak pidana khusus, terutama tindak pidana korupsi, seharusnya Pasal 66 Ayat (1) ini dapat dinegasikan, jadi izin dari MPD, demi kepentingan umum tidak lagi bersifat imperatif, namun dapat saja hanya berupa pemberitahuan kepada MPD karena sifat tindak pidana korupsi yang merupakan suatu extraordinary crime, sehingga diperlukan pula suatu tindakan-tindakan yang 'tidak biasa' pula dalam usaha pemberantasannya. Sebagaimana pendapat yang menyatakan bahwa tak ada satupun aturan atau ajaran yang membenarkan profesi tertentu dapat menyembunyikan kejahatan seseorang.
\end{abstract}

Kata kunci : Korupsi, Undang-Undang Jabatan Notaris, Notaris

\section{ABSTRACT}

Application of Article 66 Paragraph (1) is only carried out in the areas of criminal, not civil. If related to general crime, then the permission of MPD (now Honorary Council of Notaries) it is mandatory or imperative, if not, then the proceedings it should be deferred used until the permission of MPD, as a form of protection Notary, unless the Notary it will be examined in a criminal case that has nothing to do with the making of the notarial deed.

When dealing with special crimes, particularly corruption, should Article 66 Paragraph (1) can be negated, so the permission of MPD, the public interest no longer is imperative, but it might be only a notification to the MPD because of the nature of corruption offenses is an extraordinary crime, so it is also necessary actions an 'unusual' also in the eradication effort. As it has been argued that no single rule or doctrine that justifies certain professions a person can conceal the crime.

Keywords: Corruption, article 66, paragraph 1, Notary 
Pendahuluan

Salah satu hal yang selalu menjadi polemik ketika dibahas mengenai Undang-Undang Jabatan Notaris (UUJN, sebagaimana dimaksud Undang-Undang Nomor 30 Tahun 2004 tentang Jabatan Notaris sebagaimana telah diubah dengan Undang-Undang Nomor 2 Tahun 2014 tentang Perubahan Undang-Undang Nomor 30 Tahun 2004 tentang Jabatan Notaris) adalah mengenai penafsiran terhadap Pasal 66 ayat (1) UUJN. Adapun isinya adalah sebagai berikut:

"Untuk kepentingan proses peradilan, penyidik, penuntut umum, atau hakim dengan persetujuan majelis kehormatan Notaris Daerah berwenang:

a. mengambil fotokopi Minuta Akta dan/atau surat-surat yang dilekatkan pada Minuta Akta atau Protokol Notaris dalam Penyimpanan Notaris; dan

b. memanggil Notaris untuk hadir dalam pemeriksaan yang berkaitan dengan akta yang dibuatnya atau Protokol Notaris yang berada dalam penyimpanan Notaris."

Dengan membaca pasal a quo, dapat diterjemahkan bahwa bunyi pasal tersebut ditujukan dalam perkara pidana, bukan perdata. hal ini didasarkan pada: Pertama, mengenai kepentingan pasal tersebut di atas adalah demi kepentingan proses peradilan, penyidik, penuntut umum, atau hakim (Habib Adjie, 2008). Kalimat ini harus diinterpretasikan secara utuh dalam 1 kalimat, bukan per kata. Kedua, sebagaimana pendapat dari Habib Adjie (jika Notaris berkedudukan sebagai tergugat), bahwa jika seorang Notaris digugat secara perdata, maka izin dari Majelis
Pengawas Daerah (MPD) tidak diperlukan, karena gugatan perdata merupakan hak setiap orang jika merasa ada hak-haknya yang terlanggar oleh suatu Akta Notaris, sebagaimana postulat dasar persona standi in judicio (orang yang mempunyai hak untuk berperkara di pengadilan).

Ketiga, dalam ranah perdata (jika Notaris atau akta Notaris menjadi objek pemeriksaan dalam suatu peradilan perkara perdata), akta Notaris yang bersifat sebagai akta otentik merupakan suatu alat bukti yang penuh dan sempurna tanpa perlu alat bukti lain (probatio plena) (John Gilissen dan Frits Gorle, 2007) atau sebagaimana yang diungkapkan oleh Subekti bahwa akta otentik bersifat volledig bewijs, artinya apabila suatu pihak mengajukan suatu akta resmi, hakim harus menerimanya dan menganggap apa yang dituliskan di dalam akta itu, sungguh-sungguh telah terjadi, sehingga hakim tidak boleh memerintahkan penambahan pembuktian lagi (Subekti, 2001).

Teori tersebut di atas jika dihubungkan dengan salah satu asas proporsionalitas atau ketidakberpihakan Notaris kepada salah satu pihak, maka sebaiknya cukup akta Notaris itu saja yang 'berbicara' di pengadilan tanpa perlu Notaris hadir (A. Kohar, 1983), karena kehadirannya justru dapat membuat posisi Notaris memberatkan salah satu pihak dalam perkara perdata tersebut. Hal inilah yang lalu dikenal sebagai Hak Ingkar Notaris (sebagaimana terdapat pada Pasal 1909 ayat (3) KUHPerdata dan diatur pula pada Pasal 16 ayat (1) huruf $f$ Undang-Undang Nomor 2 
Tahun 2014 tentang Perubahan Undang-Undang Nomor 30 Tahun 2004 tentang Jabatan Notaris) (Sudikno Mertokusumo, Mengenal Hukum: Suatu Pengantar, Cetakan Kedua, Liberty, Yogyakarta).

Keempat, dengan

memperhatikan Pasal 3 juncto Pasal 9 Peraturan Menteri Kehakiman Hukum Dan Hak Asasi Manusia Republik Indonesia Nomor : M. 03.HT.03.10 Tahun 2007 Tentang Pengambilan Minuta Akta Dan Pemanggilan Notaris, yang berisi pengambilan terhadap fotokopi minuta akta hanya dimungkinkan jika ada dugaan tindak pidana berkaitan dengan minuta akta dan atau surat-surat yang dilekatkan pada minuta akta atau protokol notaris dalam penyimpanan notaris, ada penyangkalan keabsahan tanda tangan dari paha pihak, dugaan pengurangan atau penambahan dari Minuta Akta atau ada dugaan notaris melakukan pemunduran tanggal akta (antidatum).

Lalu memperhatikan pula pasal 14 ayat (1) Peraturan Menteri a quo, bahwa penyidik, Penuntut Umum, atau Hakim untuk kepentingan proses peradilan dapat memanggil notaris sebagai saksi, tersangka atau terdakwa dengan mengajukan permohonan tertulis kepada MPD, namun sebagaimana ketentuan Pasal 66 ayat (1) Undang-Undang Nomor 2 Tahun 2014 tentang Perubahan UndangUndang Nomor 30 Tahun 2004 tentang Jabatan Notaris, persetujuan tersebut kini ada pada Majelis Kehormatan Notaris.

Berkaitan dengan ketentuan tersebut, dengan mengutip pendapat Machteld Boot, "every legal norm needs interpretation" (Eddy O.S. Hiariej, 2009,
Asas Legalitas dan Penemuan Hukum Dalam Hukum Pidana, Erlangga, Jakarta ), yang artinya setiap norma hukum membutuhkan interpretasi, dengan menggunakan interpretasi teleologis/sosiologis (Sudikno Mertokusumo, 2007), pada dasarnya pasal ini dimaksudkan untuk melindungi profesi Notaris itu sendiri (Hendry Julian Noor, 2010), hal ini pun juga yang diyakini oleh Habib Adjie, bahwa Pasal 66 ayat (1) ini juga ditujukan agar para Notaris mendapat perlindungan yang proporsional ketika menjalankan tugas jabatan sebagai Notaris (Hendry Julian Noor, 2010).

Sebagaimana ketentuan dalam Undang-Undang Nomor 30 Tahun 2004 tentang Jabatan Notaris, sebelum tanggung jawab "persetujuan" tersebut diserahkan kepada Majelis Kehormatan Notaris berdasarkan Undang-Undang Nomor 2 Tahun 2014 tentang Perubahan Undang-Undang Nomor 30 Tahun 2004 tentang Jabatan Notaris, tanggung jawab tersebut dipegang oleh Majelis Pengawas Daerah (MPD). Dalam melakukan pemeriksaan, MPD harus objektif dalam melakukan pemeriksaan atau meminta keterangan dari Notaris.

MPD harus menempatkan akta Notaris sebagai objek pemeriksaan, bukan menempatkan diri Notaris sebagai objek pemeriksaan, sehingga yang menjadi fokus atau ukuran pemeriksaan tersebut adalah tata cara atau prosedur dalam pembuatan akta (Hendry Julian Noor, 2010). Dalam prakteknya, pasal a quo diterapkan tidak seragam, ada beberapa kebijakan yang diterapkan oleh MPD, yaitu: pertama, tidak jarang ada MPD yang menolak apapun permintaan penyidik 
untuk memeriksa Notaris yang berkaitan dengan akta yang dibuat atau oleh Notaris yang dipermasalahkan oleh para pihak atau pihak lainnya.

Kedua, ada MPD yang mengabulkan permohonan penyidik untuk memeriksa Notaris. Ketiga, ada juga MPD yang melihat pokok permasalahannya terlebih dahulu, untuk kemudian menjadi pertimbangan apakah permohonan izin pemeriksaan Notaris itu ditolak atau dikabulkan oleh MPD (Habib Adjie).

Kebijakan yang dilakukan oleh MPD tersebut, berdasarkan pengalaman penulis, terkadang dilakukan dengan mempertimbangkan keberadaan Notaris dalam suatu kasus yang dihadapi. Artinya MPD juga melakukan penilaian terhadap kasus itu, apakah Notaris atau akta Notaris itu memang dibutuhkan secara vital dalam kasus tersebut. Karena terkadang ada penilaian dari MPD penyidik tidak memahami tentang tugas dan wewenang Notaris. Walaupun biasanya Notaris atau akta notaris tetap dibutuhkan untuk dihadirkan dalam suatu peradilan pidana, sebagaimana sifat dari hukum pidana, yaitu mencari kebenaran materiil yang artinya hakim wajib aktif dan menggali segala hal-hal materiil yang dapat menguatkan alat bukti, pertimbangan, keyakinan, serta putusan hakim.

Berdasarkan tugas-tugas yang diemban Notaris dalam aspek formal akta Notaris, setidaknya tugas-tugas itu dapat bersinggungan dengan sanksisanksi pidana sebagaimana pada pasalpasal berikut dalam KUHP: Pasal 263 ayat (1) dan (2), Pasal 264, Pasal 266, Pasal 55 jo. Pasal 263 ayat (1) dan (2), atau Pasal 264, atau Pasal 266, serta Pasal 56 ayat (1) dan (2) jo. Pasal 263 ayat (1) dan (2), atau Pasal 264, atau Pasal 266. Namun, pemidanaan terhadap Notaris ini dapat saja dilakukan dengan memperhatikan batasan (Habib Adjie) :

Pertama, ada tindakan hukum Notaris dari aspek formal akta yang dilakukan secara sengaja (witten willen / mengetahui dan menghendaki) dan direncanakan, bahwa akta yang dibuat di hadapan Notaris atau oleh Notaris bersama-sama untuk dijadikan dasar melakukan suatu tindak pidana. Kedua, ada tindakan hukum dari Notaris dalam membuat akta di hadapan atau oleh Notaris yang jika diukur dengan parameter UUJN, hal itu tidak sesuai dengan UUJN. Ketiga, tindakan Notaris tersebut tidak sesuai menurut instansi berwenang untuk menilai tindakan suatu Notaris, dalam hal ini Majelis Pengawas Notaris (Habib Adjie), kini hal tersebut dipegang oleh Majelis Kehormatan Notaris.

Saat ini, urgensi kepentingan penyidikan maupun peradilan berkaitan dengan keberadaan Notaris tidak hanya pada tindak pidana umum saja, karena dengan semakin berkembangnya zaman dan teknologi, banyak pula kejahatan yang dilakukan memanfaatkan profesi Notaris untuk menyembunyikan kejahatannya, misalnya menggunakan Notaris untuk melakukan pencucian uang dari hasil melakukan korupsi (misalnya dengan jula-beli saham, mendirikan perseroan, jual beli badan usaha, dan lain-lain) (Hendry Julian Noor). 


\section{Pasal 66 ayat (1) UUJN vs UU TIPIKOR}

Dengan memperhatikan bunyi pasal 66 ayat (1) UUJN, dapat disimpulkan bahwa ketentuan di dalamnya bersifat imperatif atau wajib (Hendry Julian Noor), karena tidak ada klausula eksepsional yang terdapat di dalamnya. Artinya wajib di sini berarti pula baik ketika berhadapan dengan tindak pidana umum maupun dengan tindak pidana khusus. Berkaitan dengan tindak pidana umum, penulis cukup setuju dengan pendapat tersebut, namun penulis tidak sependapat jika ketentuan pasal 66 ayat (1) ini juga diberlakukan secara mutlak pula ketika berhadapan dengan suatu tindak pidana khusus, terutama korupsi, bahkan penulis setuju jika pasal ini dapat disimpangi jika berhadapan dengan tindak pidana korupsi. Mengapa demikian?

Pertama, kiranya hampir semua pihak akan setuju dan sependapat dengan penulis bahwa korupsi merupakan suatu kejahatan yang bersifat sebagai extraordinary crime (kejahatan luar biasa), yang telah merongrong sistem keuangan dan hukum Indonesia sangat lama. Karena sudah tergolong luar biasa, maka sesuai dengan kesepakatan kita dengan dunia internasional (Eddy O.S. Hiariej, 2008) bahwa kejahatan ini harus dilawan dengan cara yang luar biasa (extraordinary) pula.

Kedua, adanya tindak pidana lain yang berkaitan dengan tindak pidana korupsi, dengan memperhatikan bunyi pasal 35 ayat (1) (mengenai kewajiban setiap orang memberikan keterangan baik sebagai saksi maupun sebagai ahli) jo. Pasal 22 (mengenai dengan sengaja tindak memberi keterangan atau memberi keterangan tidak benar) jo. Pasal 36 (kewajiban memberikan kesaksian yang juga berlaku bagi mereka yang karena pekerjaan, harkat dan martabat, atau jabatannya diwajibkan menyimpan rahasia) UU Nomor 31 tahun 1999 jo. UU Nomor 20 Tahun 2001 tentang tindak pidana korupsi, sebagai konsekuensi hukum dari Pasal 1909 ayat (3) KUHPerdata dan diatur pula pada Pasal 16 ayat (1) huruf e UUJN, bahwa Notaris juga merupakan suatu pekerjaan atau jabatan yang diwajibkan menyimpan rahasia, maka Notaris wajib memberikan kesaksian apabila dibutuhkan dan hal ini mengikuti hukum acara pidana yang berlaku dalam tindak pidana korupsi, artinya dalam hal tersebut, tidak memerlukan izin dari MPD, namun bisa hanya dengan pemberitahuan kepada MPD (Wahyu Kencana Wiguna, 2010), kini hal tersebut digantikan oleh Majelis Kehormatan Notaris.

Pasal 22 UU Pemberantasan Tindak Pidana Korupsi pada intinya bertujuan untuk mempermudah pengungkapan kasus korupsi (Mahrus Ali, 2011). Pada dasarnya di sini ada pertentangan antara UUJN dengan UU Tindak Pidana Korupsi, yang manakah yang diberlakukan? Menurut hemat penulis, berdasarkan asas lex specialis sistematis (Jan Remmelink, 2003) yang merupakan derogat dari asas lex specialis derogat legi generalis, maka yang seharusnya didahulukan adalah UU Tindak Pidana Korupsi. Ada 3 parameter untuk menyatakan suatu aturan tersebut bersifat sebagai aturan yang bersifat khusus, yaitu: 1) aturan materiilnya bersifat khusus atau 
menyimpang dari aturan umunya; 2) aturan formilnya pun bersifat khusus; serta 3) adresat/tujuan aturan tersebut jelas ditujukan kepada siapa (Eddy O.S. Hiariej).

Dengan memperhatikan kedua UU a quo, dapat disimpulkan sebagai berikut: 1) secara materiil jelas bahwa UU TIPIKOR menyimpang dari ketentuan umum yang ada (KUHP), dan UUJN memang tidak ada ketentuan pidana di dalamnya; 2) secara formil UUJN dan UU TIPIKOR dapat dikatakan sama-sama menyimpang dari ketentuan umum dalam KUHAP. Penyimpangan UU TIPIKOR dari KUHAP sudah jelas dengan adanya Komisi Pemberantasan Korupsi, adanya pengadilan tersendiri (Pengadilan TIPIKOR sebagaimana dimaksud UU Nomor 46 Tahun 2009), dan ke-khusus-an lainnya dari aturan formil UU TIPIKOR, sedangkan UUJN menyimpang karena harus adanya izin dari MPD apabila berkaitan dengan kasus pidana. 3) adresat pada UUJN jelas disebutkan ditujukan bagi jabatan Notaris (sebagaimana asas titulus est lex/judul menentukan isi undangundang), namun dengan memperhatikan pasal 36 UU TIPIKOR, mengenai kewajiban memberikan kesaksian yang juga berlaku bagi mereka yang karena pekerjaan, harkat dan martabat, atau jabatannya diwajibkan menyimpan rahasia, sebagaimana telah disebutkan di atas bahwa sebagai konsekuensi bunyi pasal 16 ayat (1) huruf e UUJN, maka dapat diinterpretasikan secara teleologis bahwa adresat dari pasal 36 UU TIPIKOR itu juga ditujukan kepada jabatan-jabatan pemegang rahasia, seperti Jabatan Notaris. Dengan memperhatikan secara kumulatif terhadap ketiga parameter tersebut sebagai syarat penerapan asas lex specialis sistematis, oleh karenanya penulis berpendapat UU TIPIKOR harus lebih didahulukan dari UUJN.

Ketiga, posisi dilematis dari MPD (kini oleh Majelis Kehormatan Notaris). Di satu sisi, MPD (Majelis Kehormatan Notaris) berfungsi sebagai pengawas dan pelindung profesi Notaris apabila diperiksa dalam suatu perkara pidana yang terkait dengan pembuatan aktanya, namun di sisi lain apabila berkaitan dengan korupsi, MPD (Majelis Kehormatan Notaris) dapat dikatakan 'harus' memenuhi permintaan pengadilan, penyidik, penuntut umum, maupun hakim. Hal ini dilakukan terkait dengan hal yang dikenal sebagai obstruction of justice yang juga termasuk tindak pidana lain yang berkaitan dengan tindak pidana korupsi, sebagaimana tertuang dalam Article 25 UNCAC yang juga diatur oleh Pasal 21 UU Nomor 31 Tahun 1999 jo. UU Nomor 20 Tahun 2001, yang berbunyi: "setiap orang yang dengan sengaja mencegah, merintangi, atau menggagalkan secara langsung tidak langsung penyidikan, penuntutan, dan pemeriksaan di sidang pengadilan terhadap tersangka ataupun terdakwa ataupun para saksi dalam perkara korupsi, dipidana dengan pidana ...".

Pengertian dari pasal a quo, kata "mencegah" itu bermakna perbuatan atau usaha (secara aktif/nyata) yang dilakukan agar suatu tindak pidana korupsi tidak dilakukan penyidikan, penuntutan dan diadili dipengadilan (perkara belum berjalan). Sedangkan makna "menghalangi" diartikan sebagai perbuatan atau usaha (secara aktif/nyata) yang dilakukan agar suatu 
tindak pidana korupsi dihalangi atau dipersulit dilakukan penyidikan, penuntutan, dan diadili di pengadilan (proses perkara sudah berjalan). Dan makna "menggagalkan" adalah perbuatan atau usaha (secara aktif/nyata) yang dilakukan agar suatu tindak pidana korupsi yang sudah dilakukan penyidikan, penuntutan, dan diadili di pengadilan menjadi tidak dilaksanakan (proses perkara juga sudah berjalan) (Mahrus Ali ).

Rumusan delik yang tercantum dalam pasal a quo, juga yang terdapat pada pasal 35 ayat (1) jo. Pasal 22 jo. Pasal 36 UU Nomor 31 tahun 1999 jo. UU Nomor 20 Tahun 2001 tentang tindak pidana korupsi, jelas bahwa delik pada pasal-pasal a quo merupakan delik omisi, yang selalu merupakan delik formil, yaitu adanya suatu kewajiban untuk melakukan perbuatan positif tertentu. Jadi, terpenuhinya delik ini adalah ketika orang yang diperintahkan menurut undang-undang untuk berbuat sesuatu, namun dia tidak melakukan apa yang seharusnya diperbuat (.E Sahetapy). Dengan kata lain, apabila MPD (Majelis Kehormatan Notaris) ketika berhadapan dengan kasus korupsi tidak memberikan izin yang seharusnya diberikan dalam rangka memeriksa Notaris ataupun akta Notaris, maka hal itu dapat diancam dengan pidana sebagaimana tersebut di atas.

Dari semua hal-hal tersebut di atas, ada beberapa catatan penulis berkaitan dengan Pasal 66 ayat (1) UUJN. Pertama, bahwa terkait penerapan pasal ini, hanyalah

\section{Simpulan}

dilakukan pada ranah pidana, bukan perdata. Kedua, jika terkait dengan tindak pidana umum, maka izin dari MPD (kini Majelis Kehormatan Notaris) itu bersifat wajib atau imperatif, jika tidak, maka proses perkara itu seharusnya dapat ditangguhkan dulu sampai ada izin dari MPD (kini Majelis Kehormatan Notaris) sebagai bentuk perlindungan Jabatan Notaris, terkecuali jika Notaris itu akan diperiksa dalam perkara pidana yang tidak ada hubungannya dengan pembuatan akat Notaris tersebut.

Ketiga, apabila berhadapan dengan tindak pidana khusus, terutama tindak pidana korupsi, seharusnya pasal 66 ayat (1) ini dapat dinegasikan, jadi izin dari MPD (kini Majelis Kehormatan Notaris), demi kepentingan umum tidak lagi bersifat imperatif, namun dapat saja hanya berupa pemberitahuan kepada MPD (kini Majelis Kehormatan Notaris), karena sifat tindak pidana korupsi yang merupakan suatu extraordinary crime, sehingga diperlukan pula suatu tindakan-tindakan yang 'tidak biasa' pula dalam usaha pemberantasannya. Sebagaimana pendapat dari Yunus Husein, bahwa tak ada satupun aturan atau ajaran yang membenarkan profesi tertentu dapat menyembunyikan kejahatan seseorang (Yunus Husein ).

\section{Daftar Pustaka}

Adjie, Habib "Aktualisasi Jabatan
Notaris Pasca Lima Tahun
Berlakunya Undang-Undang
Jabatan Notaris (UUJN)",
disampaikan dalam Kuliah
Umum Program Studi Magister
Kenotariatan Fakultas Hukum


UGM, Fakultas Hukum UGM, Yogyakarta, 19 Oktober 2009.

Adjie, Habib, 2008, Sanksi Perdata dan Administratif Terhadap Notaris Sebagai Pejabat Publik, Cetakan Pertama, PT. Refika Aditama, Bandung.

Ali, Mahrus, 2011, Hukum Pidana Korupsi Di Indonesia, Cetakan Pertama.

Eddy O.S. Hiariej, "Disentralisasi Korupsi : Urgensi Pengadilan TIPIKOR dan KPK Di Daerah", disampaikan dalam Diskusi Publik Disentralisasi Korupsi : Carut Marut Otonomi Daerah, Kerjasama Pusat Kajian AntiKorupsi Fakultas Hukum Universitas Gadjah Mada Dan Dewan Perwakilan Rakyat Daerah Republik Indonesia, Fakultas Hukum Universitas Gadjah Mada, Yogyakarta, 27 september 2008.

Gilissen John, dan Frits Gorle, 2007, Sejarah Hukum: Suatu Pengantar, Cetakan Kedua, PT. Refika Aditama, Bandung.

Hiariej, Eddy O.S. "Grey Area Penegakan Hukum Pidana Antara Tindak Pidana Perbankan Dengan Tindak Pidana Korupsi”, disampaikan dalam Diskusi Terbatas Kegiatan Perbankan Dalam Perspektif Tindak Pidana Korupsi, Kerjasama Fakultas Hukum Universitas Gadjah Mada Dan Bank Indonesia, Hotel Santika, Yogyakarta, 30 Oktober 2008

Hiariej, Eddy O.S. 2009, Asas Legalitas dan Penemuan Hukum Dalam
Hukum Pidana, Erlangga, Jakarta.

Husein, Yunus, 2008, Negeri Sang Pencuci Uang, Cetakan Pertama, Pustaka Juanda Tigalima, Jakarta.

Julian Noor, Hendry 2010, Jasa Notaris Sebagai Salah Satu Upaya Dalam Menegakkan Rezim Anti Pencucian Uang (Tesis), Magister Kenotariatan Fakultas Hukum Universitas Gadjah Mada, Yogyakarta.

Kohar, A. 1983, Notaris Dalam Praktek Hukum, Alumni, Bandung.

Mertokusumo, Sudikno, 2007, Penemuan Hukum Sebuah Pengantar, Cetakan Kelima, Liberty, Yogyakarta.

Mertokusumo, Sudikno, Mengenal Hukum: Suatu Pengantar, Cetakan Kedua, Liberty, Yogyakarta.

Remmelink, Jan, 2003, Hukum Pidana : Komentar Atas Pasal-Pasal Terpenting Dari Kitab UndangUndang Hukum Pidana Belanda Dan Padanannya Dalam Kitab Undang-Undang Hukum Pidana Indonesia, PT Gramedia Pustaka Utama, Jakarta.

Sahetapy, J.E 1995, Hukum Pidana, Liberty, Yogyakarta.

Subekti, 2001, Pokok-Pokok Hukum Perdata, Cetakan Ke-21, PT. Intermasa, Jakarta.

Wiguna, Wahyu Kencana, 2010, Hak Ingkar Notaris Dalam Hukum Pembuktian Pidana Di Indonesia (Tesis), Magister Kenotariatan Fakultas Hukum Universitas Gadjah Mada, Yogyakarta. 